\title{
PROSES PERKULIAHAN*
}

\author{
Ismail Suardi Wekke \\ Sekolah Tinggi Agama Islam Negeri (STAIN) Sorong \\ Email: iswekke@gmail.com
}

\begin{abstract}
ABSTRAK
Dalam empat pekan, terdapat enam aktifitas yang perlu dilakukan mahasiswa dalam proses perkuliahan mata kuliah metode penelitian kualitatif. Aktifitas ini sebagai latihan awal untuk memberikan pengalaman belajar mahasiswa secara bersama dalam sebuah kelompok. Selanjutnya, di paruh kedua perkuliahan akan dilaksanakan secara mandiri. Dengan pengalaman yang ada sebelum itu, akan menjadi awalan dalam menuntaskan latihan di bagian kedua semester berlangsung.
\end{abstract}

Kata kunci: perkuliahan, proses, latihan

\section{PENDAHULUAN}

Perkuliahan menjadi bagian dalam melatih kemampuan mahasiswa. Sehingga dengan proses yang berjalan selama satu semester akan memberikan pengalaman pembelajaran. Sementara itu, perkuliahan seperti mata kuliah Metode Penelitian Kualitatif tidak hanya memerlukan pemahaman pada aspek teoritis saja tetapi juga pada kemampuan untuk langsung melaksanakan secara aplikatif. Setelah itu, mahasiswa akan kembali menelaah proses aktifitas yang sudah dilaksanakan dalam perkuliahan.

Winarni (2013) bahkan secara khusus mengintegrasikan pendidikan karakter dalam proses pembelajaran. Ini bermakna bahwa perkuliahan menjadi media untuk membentuk karakter siswa dan juga mahasiswa. Muhtadi (2009) mengemukakan diperlukan sebuah antusiasme mahasiswa untuk senantiasa aktif dalam proses pembelajaran. Sebagaimana Prabowo (2013) juga mengidentifikasi bahwa dengan studi kasus, mahasiswa akan mendapatkan latihan dalam membangun pemahaman terhadap topik-topik perkuliahan.

Kejujuran wajib menjadi instrumen utama seluruh proses kehidupan, termasuk dalam kegiatan akademik (Ardinansyah, Tenrisau, Aslim, \& Wekke, 2018). Bahkan di perguruan tinggi sekalipun, jamak ditemukan ketidakjujuran. Sebagai aktivitas mendekati Tuhan, maka perkuliahan idealnya adalah aktivitas yang dijiwai semangat ketuhanan (Sabri, Ikhsan, \& Wekke, 2018). Tidak boleh sedetikpun ada aktivitas yang culas. Untuk memudahkan dalam proses perkuliahan, salah satu alat yang dapat digunakan adalah fasilitas teknologi informasi (Nur, Sabara, \& Wekke, 2018). Tidak hanya itu,

\footnotetext{
* Materi perkuliahan untuk Mata Kuliah Metode Penelitian Kualitatif, Jurusan Dakwah dan Komunikasi, Semester genap 2018/2019, Sekolah Tinggi Agama Islam Negeri (STAIN) Sorong.
} 


\section{PROSES PERKULIAHAN}

Dalam empat pekan, mahasiswa akan melaksanakan aktifitas beragam yang terbagi atas fase sebagai berikut:

Pertama, Selasa (12/3) menyelesaikan pendahuluan sesuai topik kelompok.

Kedua, Selasa (19/3) menyelesaikan kajian literatur. Untuk pekan ini bisa diskusi terbimbing dengan Asrori, M.Pd.

Ketiga, secara individu, membaca buku studi agama: Amin Abdullah. Menuliskan analisis ataupun ringkasan dari hasil bacaan.

Keempat, Selasa (29/3) dua aktivitas: (diskusi terbimbing dengan Asrori, M.Pd.)

1) Menuliskan abstract untuk dikirim ke Student Forum on Sustainable Development, ICEASD. Untuk informasi selengkapnya, lihat di http://stie-66.ac.id/iceasd/

2) Melanjutkan pada hasil penelitian, untuk latihan kelompok.

Kelima, Selasa (2/4) menyiapkan paper untuk UTS. Menyelesaikan struktur paper kelompok. Batas unggah ke Academia tanggal 7 April pukul 23.59 WIT. Sehingga pertemuan tanggal 89/April, mulai mendiskusikan paper individual.

\section{PENJELASAN TEKNIS TEMA-TEMA}

Setiap kelompok wajib menyelesaikan latihan untuk menyusun artikel sebagai latihan awal dalam fase pertama perkuliahan. Hasil latihan tersebut menjadi kumpulan untuk penilaian Ujian Tengah Semester (UTS). Hanya saja, untuk sampai pada kelengkapan artikel, maka perlu tahapan perpekan dalam proses perkuliahan.

Selanjutnya, komposisi sebuah artikel dilengkapi dengan pola pendahuluan, hasil, pembahasan, dan penutup. Kemudian ditambah dengan daftar pustaka. Bagian awal ditambahkan dengan judul, nama penulis beserta afiliasi dan email, dan abstrak.

Progress setiap pekan perlu diunggah ke laman Academia untuk menjadi pemantauan kemajuan tiap pekan. Demikian pula perlu membaca buku tulisan Amin Abdullah sebagai dasar untuk menjelaskan seperti apa kajian keagamaan yang dapat dilakukan.

\section{KONSTRUKSI TEORITIS}

Perkuliahan terkait dengan karakteristik masing-masing mata kuliah. Untuk mata kuliah metode penelitian, tidak cukup hanya dengan metode ceramah dan diskusi saja. Namun, mata kuliah ini memerlukan bacaan yang lengkap sehingga memungkinkan adanya penjelasan yang memadai untuk sebuah topik. Perkuliahan ini memberikan kesempatan kepada mahasiswa untuk 
mengembangkan kemampuan secara otonomi (Salam, Prabowo, \& Supardi, 2017). Dengan pola ini memungkinkan adanya kemandirian dalam belajar.

Perkuliahan metode penelitian dapat dikembangkan dengan menggunakan pelbagai inovasi (Tegeh \& Kirna, 2013). Melengkapi proses perkuliahan dengan beberapa rangkaian kegiatan, akan memudahkan mahasiswa untuk mengikuti alur dan langkah dalam penelitian itu sendiri. Untuk itu, selain keterampilan yang wajib dikuasai mahasiswa juga perlunya motivasi yang dibangun untuk selalu mengikuti perkuliahan dengan antusias (Dariyo, 2004).

\section{PENUTUP}

Artikel ini menjadi sebuah panduan untuk memperkaya aktifitas perkuliahan. Dengan demikian, perkuliahan melalui latihan demi latihan akan memperkaya proses penguasaan mahasiswa dalam matakuliah yang ada. Panduan ini hanya berisi bagian yang standar. Bisa jadi, mahasiswa dapat melakukan pengembangan sehingga capaian pembelajaran lebih komprehensif dibandingkan dengan sasaran yang ditargetkan.

\section{DAFTAR PUSTAKA}

Ardinansyah, A., Tenrisau, D., Aslim, F., \& Wekke, I. S. (2018). Ketidakjujuran Akademik Dalam Pendidikan Tinggi.

Dariyo, A. (2004). Pengetahuan tentang penelitian dan motivasi belajar pada mahasiswa. Jurnal psikologi, 2(1), 44-48.

Muhtadi, A. (2009). Implementasi Konsep Pembelajaran "Active Learning" sebagai Upaya untuk Meningkatkan Keaktifan Mahasiswa dalam Perkuliahan. Jurusan Kurikulum dan Teknologi Pendidikan FIP UNY, Majalah Ilmiah Pembelajaran.

Nur, T., Sabara, H. Z., \& Wekke, I. S. (2018). Teknik Menulis Karya Ilmiah: Dengan 8 Senjata Aplikasi Pendukung Produktivitas Riset. Deepublish.

Prabowo, A. (2013). Pembelajaran berbasis proyek untuk meningkatkan pemahaman mahasiswa atas permasalahan statistika pada perkuliahan studi kasus dan seminar. Kreano, Jurnal Matematika Kreatif-Inovatif, 3(2), 82-90.

Sabri, M., Ikhsan, M., \& Wekke, I. S. (2018). Pengalaman Paramadina sebagai Rumah Pengetahuan Berbasis Nilai-nilai Ketuhanan, Tradisi Hikmah, dan Ilmu Pengetahuan. TEOSOFI: Jurnal Tasawuf dan Pemikiran Islam, 8(2), 373-405.

Salam, A., Prabowo, P., \& Supardi, Z. I. (2017). Pengembangan perangkat perkuliahan inovatif berdasarkan tingkat otonomi pebelajar pada perkuliahan Fisika Dasar. JPPS (Jurnal Penelitian Pendidikan Sains), 4(2), 547-556.

Tegeh, I. M., \& Kirna, I. M. (2013). Pengembangan Bahan ajar metode penelitian pendidikan dengan addie model. Jurnal Ika, 11(1).

Winarni, S. (2013). Integrasi pendidikan karakter dalam perkuliahan. Jurnal Pendidikan Karakter, (1). 